\title{
Wstęp
}

\section{Numer nawiedzony}

\section{Grzegorz Grochowski}

TEKSTY DRUGIE 2016, NR 2, S. 7-13

DOI: $10.18318 /$ td.2016.2.1

$\mathrm{J}$ edną z ciekawszych i bardziej wpływowych tendencji w dzisiejszej humanistyce pozostaje od pewnego czasu kierunek odwołujący się do spirytystycznych metafor widma, zjawy, mediumicznego pośrednictwa czy też nawiedzenia. Chciałoby się niemal powiedzieć, że widma spirytyzmu nawiedzają racjonalne myślenie. Całkiem niedawno ukazały się aż dwie ważne monografie poświęcone tej problematyce ${ }^{1}$, w ostatnich miesiącach odbyła się wielowątkowa konferencja tematyczna², pod koniec roku zapowiadana jest kolejna ${ }^{3}$, całości obrazu dopełnia zaś nagły przyrost szczegółowych opracowań, reprezentujących różne dyscypliny (od filozofii, przez

1 A. Marzec Widmontologia. Teoria filozoficzna i praktyka artystyczna ponowoczesności, Fundacja Bęc Zmiana, Warszawa 2015; J. Momro Widmontologie nowoczesności. Genezy, Wydawnictwo IBL PAN, Warszawa 2014 .

2 Widma Derridy, Warszawa, 11-12 stycznia 2016 roku.

3 Widma-anachroniczne czytanie sztuki, Poznań, 14-15 października 2016 roku.

\section{Grzegorz Grochow-}

ski - dr, adiunkt w Pracowni Poetyki Teoretycznej Instytutu Badań Literackich Polskiej Akademii Nauk w Warszawie. Zajmuje się poetyką, genologią i analizą dyskursu. Autor książki Tekstowe hybrydy (2000), współautor Słownika pojęć i tekstów kultury (2002). Członek kolegium redakcyjnego „Tekstów Drugich". Kontakt: grzegorzgrochowski@hotmail.com 
estetykę i poetykę, aż po medioznawstwo ${ }^{4}$ ). Ponieważ nurt ten wciąż zachowuje żywotność i atrakcyjność, dostarczając krytyce zarówno konkretnych narzędzi opisu, jak i perspektyw ogólnych przewartościowań poznawczych, otworzyliśmy łamy obecnego numeru dla wszelkich zjaw, majaków, zwidów, omamów, duchów, widziadeł, i upiorów.

Choć współczesna „teoria nawiedzenia” przyjmuje wiele postaci, za punkt wyjścia całej formacji należy uznać projekt analizy spektralnej, wprowadzony przez Jacques'a Derridę na ostatnich stronach Prawdy w malarstwie (na których filozof wspomina m.in. o "halucynogennej fikcji”, „widmowych kończynach”, „przywołaniu duchów” czy "sobowtórze w postaci nawiedzającego upiora"5), a rozwinięty w Widmach Marksa6, gdzie zyskał bardziej rozbudowaną formę „widmontologii" (przyjmuję takie tłumaczenie autorskiego neologizmu, zgodnie z zasadą obowiązującą w monografiach Andrzeja Marca i Jakuba Momry, choć niekiedy bywa on również oddawany za pomocą kalki hauntologia), a więc ogólnej koncepcji świata nawiedzanego ustawicznie przez fantomy niespełnionych potencjalności. Pośrednie zapowiedzi zbliżonego ujęcia można też odnaleźć we wcześniejszych książkach „duchologicznych" (czyli Glas i O duchu), a zwłaszcza we wstępie do znanej książki Nicolasa Abrahama i Márii Török o kryptonimii, stanowiącej niewątpliwie jedno z głównych źródeł tego sposobu myślenia. Przekład klasycznego eseju Derridy, poprzedzającego psychoanalityczne rozważania obojga autorów, mamy przyjemność udostępnić w niniejszym numerze.

Główną cechą widma wydaje się - już na poziomie potocznego rozumienia - niepokojąca zjawiskowość czegoś niematerialnego, co tymczasowo zyskuje zauważalne kształty, niespodziewanie wyłania się z mrocznych zaświatów i znika, powracając w rytmie kolejnych nawiedzeń (jak choćby statek widmo z żeglarskich legend). Nad tą zwyczajową wykładnią nadbudowują się akademickie interpretacje, w których fantomowa postać ma zwykle stanowić figurę paradoksalnego istnienia poza opozycjami (obecności/nieobecności, ducha/materii, aktywności/bierności, ożywienia/

4 Zob. np.: M. Bielecki Widma nowoczesności. Ferdydurke Witolda Gombrowicza, Wydawnictwo IBL PAN, Warszawa 2014; M. Kowalska Dialektyka poza dialektyką. Od Bataille'a do Derridy, Aletheia, Warszawa 2000 (kluczową figurą tej pracy są widma heglizmu, nawiedzające dwudziestowieczną filozofię); J. Majmurek Widma Wajdy, w: Wajda. Przewodnik Krytyki Politycznej, Wydawnictwo Krytyki Politycznej, Warszawa 2013; A. Skrendo Stanisław Barańczak: widma poezji, „Teksty Drugie” $2014 \mathrm{nr} 2$.

5 J. Derrida Prawda w malarstwie, przeł. M. Kwietniewska, słowo/obraz terytoria, Gdańsk 2003, s. 436-443. Przy zauważalnym spadku zainteresowania dekonstrukcją to właśnie program „widmowy" reprezentuje dziś najbardziej żywotną część jej dziedzictwa.

6 Właśnie ukazał się polski przekład tej książki - J. Derrida Widma Marksa, przeł. T. Załuski, PWN, Warszawa 2016. 
martwoty itp.), które zarazem jest i nie jest, zawieszone między bytem a niebytem zauważalne, choć mało uchwytne. Analiza spektralna uwydatnia więc rolę poznawczej mediatyzacji, odsłania szeroką skalę zapośredniczeń rozpiętą między biegunowymi opozycjami (w podobnym kierunku prowadziłoby też metaforyczne nawiązanie do spektrum optycznego, rozumianego jako wizualny obraz, oddający skład światła za pomocą palety monochromatycznych składowych).

Tak rozumiana zasada widmowości bywa samoistnym przedmiotem zainteresowania, ale dostarcza też wielu okazji do rozważań nad innymi konceptami, oddającymi podobną ambiwalencję, takimi jak choćby nie-miejsca Marca Augé. Kluczowa metafora widma może z kolei być traktowana jako przykład nie-pojęcia ${ }^{7}$, a więc określenia, które obejmuje rozpoznawalny zakres treściowy, ale nie zyskuje abstrakcyjnej przejrzystości ani ścisłości naukowego terminu, zachowując dynamikę i wieloznaczność tropu. Wiąże się z tym ambiwalentny status całej widmontologii jako swoistej quasi-koncepcji ${ }^{8}$, bliskiej równolegle funkcjonującym formułom, określanym np. jako myśl słaba czy parateoria. Nauka o nawiedzeniach nie jest spójną doktryną ani jednolitą metodologią, ale nie sprowadza się też do chwilowej mody, reprezentuje zaś pośrednią formę koncepcyjnego zestalenia, czyli płynną konstelację pokrewnych motywów (pojęciowych, tematycznych, światopoglądowych), obejmującą swym zasięgiem również wyraźniej dookreślone projekty autorskie (by wspomnieć np. „widmową hermeneutykę” Johna D. Caputo). Ważnym zapleczem większości podobnych ujęć wydaje się postulat "powtórnego zaczarowania” rzeczywistości, czyli szukania takich sposobów myślenia, które miałyby uwzględniać niepełną przejrzystość zjawisk i eksponować opór faktyczności wobec wymogów analizy systemowej.

Nie są to pomysły całkiem nowe, gdyż podobne charakterystyki dałoby się również przypisać wcześniejszym propozycjom Derridy, zogniskowanym wokół pojęcia śladu i projektu gramatologii. Spektralna parafraza - która zachowuje liczne powiązania z tamtymi wątkami - prowadzi jednak do zauważalnego przesunięcia akcentów, wprowadza dodatkowe implikacje i wykorzystuje dokonania innych tradycji myślowych, co prawdopodobnie zadecydowało o przedłużonym terminie jej ważności. Przede wszystkim w tym kontekście zwraca uwagę aktywna rola widma, które może nawiedzać nas niezależnie od naszych przewidywań czy zamiarów, niespodziewanie znikać i powracać, choć zwykle niechciane (jak pisze Jakub Momro: „widmo to bowiem

7 A. Masschelein The Unconcept:The Freudian Uncanny in Late-Twentieth-Century Theory, State University of New York Press, New York 2011.

8 A. Marzec Drugie życie teorii, czyli myślenie (p)o końcu, w: Od pamięci biodziedzicznej do postpamięci, red. T. Szostek, R. Sendyka, R. Nycz, Wydawnictwo IBL PAN, Warszawa 2013, s. 157. 
Rzecz niestanowiąca zwykłego przedmiotu, obiektu, który mógłby podlegać prawom poznania"9).

Ujęcie tej natrętnej zjawiskowości jako serii kompulsywnych powtórzeń pozwala zaś poszerzyć pole uwagi o pokrewne (choć zarazem nieco inaczej ukierunkowane) interpretacje psychoanalityczne. Oczywiście w takim kontekście problematyka niepokojących widziadeł kojarzy się z klasyczną (wprowadzoną jeszcze przez Freuda) koncepcją niesamowitości jako efektu zetknięcia z obcością tego, co było znane, ale zostało wyparte przez psychiczną autocenzurę. Wspomniana praca Abrahama i Török o krypcie nie była jednak powieleniem tradycyjnego schematu, a swą oryginalność zawdzięczała głównie wpisaniu fantomowych objawów w logikę międzypokoleniowego dziedziczenia traumy. Inaczej niż przy klasycznym wyparciu, mimowolny nabywca takiej schedy okazywał się podmiotem nawiedzanym przez cudze głosy, niczym spirytystyczne medium, pośredniczące w kontaktach z duchami (co często oddawano też metaforycznym obrazem brzuchomówcy). Wprowadzenie generacyjnej problematyzacji pozwoliło zaś wykorzystać rozpoznania kliniczne na potrzeby badań nad specyfiką doświadczenia historycznego i mechanizmami pamięci społecznej (zwłaszcza wszędzie tam, gdzie przedmiotem dociekań stają się zatarte winy przodków i upiory przeszłości, jak choćby w większości nurtów krytyki postkolonialnej).

W podobnym kierunku zdaje się zmierzać również zaproponowana przez Derridę reinterpretacja wątku Marksowskiego. Rolę widmowych motywów w tej wykładni można postrzegać dwojako. Z jednej strony francuski filozof wygrywa tradycję krytyczną przeciw afirmatywnym ujęciom „końca historii", które okazują się złudnymi próbami egzorcyzmowania przygodności i cierpienia z obszaru zachodniej cywilizacji (finalistyczną wersję dziejów należałoby wówczas uznać za pośrednią odpowiedź na lęki Zachodu, nękanego zmorami konfliktów i kryzysów, jakich doświadcza reszta świata). Zarazem jednak poprzez rozszczepienie „widmontologii" trwale oddziela postulowany horyzont etyczny od faktyczności jego wszelkich aktualizacji historycznych. Status ulotnych widziadeł zostaje więc przypisany kondycji wszelkich określonych projektów emancypacyjnych, konkretnych działań naprawczych i rozpoznawalnych programów ideologicznych.

Jak zresztą wiadomo, całościowy model widmowego mesjanizmu spotkał się z polemicznym odzewem zwolenników tradycyjnego marksizmu, zaniepokojonych m.in. brakiem ugruntowania przedstawianej wykładni w analizie konkretnych napięć społecznych i rezygnacją z prób sformułowania określonej doktryny politycznej (chodzi oczywiście o komentarze zebrane w tomie Ghostly Demarcations, zawierającym m.in. teksty tak znanych autorów jak Antonio Negri, Pierre Macherey, Fredric Jameson czy

9 J.Momro Widmontologie nowoczesności..., s. 475. 
Terry Eagleton) ${ }^{\mathbf{1 0}}$. Mimo tej programowej krytyki spektralne metafory są nadal wykorzystywane w pracach problematyzujących materię historyczności, choć pojawiają się na różnych poziomach ogólności, w kolejnych kontekstach pełnią często zmienne funkcje, a nieraz bywają też poddawane autorskim przekształceniom". Przykładowo Giorgio Agamben sięga po analogiczne tropy w opisie współczesnej Wenecji, przechodzącym w szerszą diagnozę cywilizacyjną, która ostatecznie prowadzi do uznania widmowości za rozpowszechnioną formę pośmiertnego życia w ponowoczesnych czasach, kiedy "wszystkie miasta i języki Europy żyją już jako duchy"12. Natomiast Slavoj Žižek nawiązuje bezpośrednio do modelu Derridy, ale wyraźnie dystansuje się wobec jego etycznego odniesienia do widmowej inności, by w zamian zaproponować własną interpretację „widmowości jako tego, co wypełnia niereprezentowalną otchłań antagonizmu, niemożliwego do ujęcia symbolicznie Realnego"13 , a co następnie staje się elementarną figurą, pierwotnym rdzeniem złożonych przedstawień ideologicznych (i co w jego opinii miałoby pomagać w analizie historyczno-społecznych uwarunkowań ideologii). Oprócz takich abstrakcyjnych uogólnień warto też wspomnieć przykłady bardziej empirycznie zorientowanych opracowań, które okazały się szczególnie efektownymi zastosowaniami spektralnej formuły na gruncie rodzimej humanistyki. Mam tu na myśli Niesamowitą Słowiańszczyznę Marii Janion - czyli próbę dotarcia do traumatycznych doświadczeń zbiorowości, wpisanych w nawykowo powtarzane praktyki społeczne - a także Fantomowe ciało króla Jana Sowy, gdzie pojawia się analiza ideologicznych fantazmatów, przesłaniających rzeczywisty rozpad struktur ustrojowych (w duchu dość bliskim przytoczonej interpretacji Žižka).

Obie prace dobrze ilustrują zauważalną skłonność spektrologii do wykraczania poza granice tradycyjnych dyscyplin, ale zarazem odwołują się do licznych przykładów tekstowych, co pozwala zapytać o ewentualne zastosowania omawianych kategorii w refleksji literaturoznawczej. W nowszych kompendiach przeglądowych widmokrytyka ${ }^{14}$ (spectral criticism) bywa nawet czasem wyodrębniana jako samodzielna orientacja, choć jej ogólna dominanta w różnych wariantach może zyskiwać odmienne

Ghostly Demarcations: A Symposium on Jacques Derrida's "Specters of Marx" (Radical Thinkers), ed. M. Sprinker, Verso, London - New York 1999.

11 Jednym z głównych wyznaczników „widmowego" ujmowania historii jest założenie asynchronicznego rozchwiania, nieuchronnego rozwarstwienia czasu, poza spoistością dziejowej teleologii.

12 G. Agamben O zaletach i niedogodnościach życia wśród widm, w: tegoż Nagość, przeł. K. Żaboklicki, W.A.B., Warszawa 2010, s. 52.

13 S. Žižek Widmo ideologii, przeł. M. Kropiwnicki, w: Žižek. Przewodnik Krytyki Politycznej, red. M. Kropiwnicki, J. Kutyła, Wydawnictwo Krytyki Politycznej, Warszawa 2009, s. 368.

B. Dąbrowski Wezwanie widmokrytyki, „'Czas Kultury" 2013 nr 2 (numer tematyczny). 
konkretyzacje ${ }^{15}$. Niektórzy badacze wydają się skłonni traktować widmowość jako całościową zasadę opisu, ze względu na niepewny status literatury oraz tymczasowość jej granic i charakterystyk (które niekiedy tracą wyrazistość, aż do całkowitego rozmycia właściwości, by kiedy indziej odzyskać rozpoznawalne kształty, często w nieoczekiwanych kontekstach) ${ }^{16}$. Paradoksalne wydaje się zresztą samo istnienie literackiej praktyki, która nieraz docierała do kresu swych możliwości, by znowu powracać w zmienionych wcieleniach. Mogą nas jednak interesować również inne zastosowania tej figury, prowadzące choćby do ujęcia literatury jako praktyki quasi-mediumicznej, pozwalającej żywym na swoistą formę obcowania ze zmarłymi, przez tworzenie wspólnej przestrzeni symbolicznych ( $w$ takim kierunku zmierzają np. niektóre sugestie Stephena Greenblatta). I wreszcie, należałoby tu zarezerwować oddzielne miejsce na analizę konkretnych utworów, aktualizujących kulturowe motywy sobowtórów, zjaw, upiorów, żywych trupów itp., w określonych kontekstach estetycznych i historycznych ${ }^{\mathbf{1 7}}$.

Widma nawiedzają racjonalną rzeczywistość, ale zwykle wymykają się porządkowi przedstawienia, więc również nasza obecna prezentacja nie może wyczerpać tematu i pozostaje ulotnym powidokiem przywołanych zjawisk. Mimo tych nieuchronnych ograniczeń próbujemy jednak zaproponować w jej obrębie jak najszersze spektrum lekturowych możliwości.

15 Dobre wyobrażenie o różnorodności zagadnień, opisywanych za pomocą "widmowego" słownika, daje np. zbiór The Spectralities Reader: Ghosts and Haunting in Contemporary Cultural Theory, ed. M.P. Blanco, E. Peeren, Bloomsbury, London - New York 2013 (zakres poruszanych kwestii rozciągałby się od zjawiskowości podmiotu i dyskursu, przez widmowe autorstwo ghostwriterów, fantomowość przekazów medialnych, konceptualizm „zdematerializowanej” sztuki, aż po topografię "miejsc nawiedzonych" i widmowe powroty kolonialnych ofiar, szukających pośmiertnego zadośćuczynienia).

16 Niektórzy autorzy przekonują, że momentem inauguracyjnym literackiej nowożytności było pojawienie się ojcowskiego widma w Hamlecie Williama Szekspira.

17 Warto przy okazji przypomnieć klasyczną analizę takich „niesamowitych" kreacji literackich, przeprowadzoną w artykule S. Wysłouch Anatomia widma („Teksty"1977 nr 2). 


\section{Abstract}

\section{Grzegorz Grochowski}

THE INSTITUTE OF LITERARY RESEARCH OF THE POLISH ACADEMY OF SCIENCES

The Haunted Issue

Grochowski outlines the main characteristics of the transdisciplinary research field that focuses on spectral analysis and its intellectual assumptions. He presents interpretations of the spectre, a key category in this research field, as well as the main scholarly contexts in which it usually appears. Grochowski also discusses the field's philosophical inspirations, its programmatic references to established intellectual traditions, as well as examples of concrete manifestations in the works of individual writers, which indicate the diversity of the field. Finally, he sketches out the areas in which similar approaches can find practical application and points out the general conditions of their evident popularity.

\section{Keywords}

spectre, hauntology, spectrality, crypt, haunting, psychoanalysis 